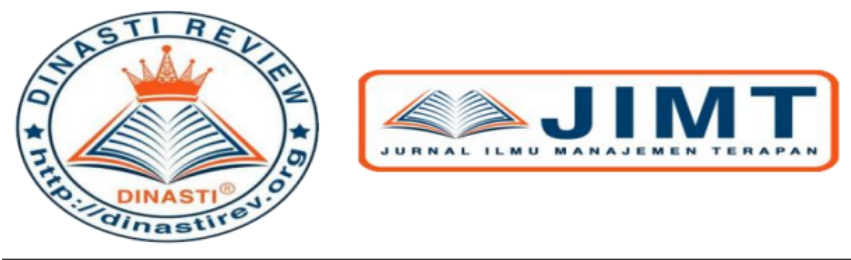

+62 878-9658-6407

087896586407

https://dinastirev.org/JIMT

editor@dinastirev.org

\title{
STRATEGI PENGEMBANGAN SUMBER DAYA MANUSIA MELALUI ANALISIS KEBUTUHAN DIKLAT DI BPSDM PROVINSI JAMBI
}

\author{
Sultoni ${ }^{1)}$ \\ 1) Badan Pengembangan Sumber Daya Manusia, Jambi, Indonesia
}

\begin{tabular}{|c|l|}
\hline ARTICLE INFORMATION & $\begin{array}{l}\text { Abstrak: Kegiatan pengembangan kompetensi yang dilakukan } \\
\text { Received: 2 Januari 2020 } \\
\text { oleh instansi pemerintah bukanlah kegiatan sporadis tetapi } \\
\text { merupakan sebuah kegiatan terencana yang berawal dari adanya } \\
\text { Issued: 11 Januari 2020 } \\
\text { kebutuhan dan rencana pengembangan kompetensi hasil dari } \\
\text { kegiatan inventarisasi jenis kompetensi yang perlu di tingkatkan } \\
\text { dari setiap PNS dan rencana pelaksanaan pengembangan } \\
\text { kompetensi yang setiap tahun tercantum dalam rencana anggaran } \\
\text { tahunan di setiap instansi (Pasal 205 ayat (1) dan (2) PP Nomor } \\
\text { 11 Tahun 2017) dengan tetap memperhatikan ketentuan } \\
\text { terpenuhinya hak dan kesempatan yang sama bagi PNS untuk } \\
\text { ikut serta dalam kegiatan pengembangan kompetensi paling } \\
\text { sedikit 20 (dua puluh) jam per tahun. Penulisan buku ini } \\
\text { menggunakan metode deskriptif analitik adalah suatu metode } \\
\text { yang berfungsi untuk mendeskripsikan atau memberi gambaran } \\
\text { terhadap obyek yang diteliti melalui data atau sampel yang telah } \\
\text { terkumpul sebagaimana adanya tanpa melakukan analisis dan } \\
\text { membuat kesimpulan yang berlaku untuk umum. Dari hasil } \\
\text { observasi didapatlah kesimpulan bahwa, Pengembangan } \\
\text { kompetensi merupakan supaya yang sistematis untuk mendorong } \\
\text { PNS untuk memenuhi kebutuhan kompetensi, Pelaksanaan } \\
\text { kegiatan pengembangan kompetensi merupakan salah satu unsur } \\
\text { dalam pengelolaan manajemen PNS dan menjadi bagian dari } \\
\text { pengembangan karir, Kegiatan pengembangan kompetensi di } \\
\text { daerah memperhatikan pada pembagian urusan kewenangan } \\
\text { sebagaimana diatur dalam lampiran undang-undang Nomor 23 } \\
\text { Tahun 2014 tentang pemerintahan daerah; } \\
\text { Kata Kunci: Kompetensi, Jenis Kompetensi, Pengembangan } \\
\text { Kompetensi }\end{array}$ \\
\hline
\end{tabular}

\section{PENDAHULUAN}

Penetapan peraturan pemerintah no.11 tahun 2017 tentang manajemen PNS sebagai peraturan pelaksana dari undang-undang No.5 Tahun 2014 tentang aparatur sipil Negara semakin mempertegas arah pengelolaan PNS agar menjadi lebih terarah untuk melaksanakan fungsi PNS dalam melaksanakan tugas. Salah satu langkah penting untuk menyusun manajemen karir PNS yang meliputi peengembangan kompetensi, pola karir, mutasi, dan promosi harus dilakukan dengan menerapkan pengembangan sumber daya manusia.

Dari beberapa bagian manajemen karir PNS diatas, pengembangan kompetensi sumber daya manusia merupakan bagian penting karena menyangkut upaya dari instansi pemerintah 
dalam meningkatkan kapasitas PNS agar memenuhi kompetensi yang di tetapkan sebagaimana tujuan diadakannya kegiatan pengembangan kompetensi yaitu upaya untuk pemenuhan kebutuhan kompetensi PNS dengan standar kompetensi jabatan dan rencana pengembangan karier (Pasal 203 Peraturan Pemerintah Nomor. 11 Tahun 2017 tentang manajemen PNS). Dengan demikian kegiatan kompetensi memiliki keterkaitan dengan standar kompetensi jabatan dan rencana pengembangan karier sehingga setiap instansi pemerintah wajib melaksanakan kegiatan pengembangan kompetensi.

Kegiatan pengembangan kompetensi yang dilakukan oleh instansi pemerintah bukanlah kegiatan sporadis tetapi merupakan sebuah kegiatan terencana yang berawal dari adanya kebutuhan dan rencana pengembangan kompetensi hasil dari kegiatan inventarisasi jenis kompetensi yang perlu di tingkatkan dari setiap PNS dan rencana pelaksanaan pengembangan kompetensi yang setiap tahun tercantum dalam rencana anggaran tahunan di setiap instansi (Pasal 205 ayat (1) dan (2) PP Nomor 11 Tahun 2017) dengan tetap memperhatikan ketentuan terpenuhinya hak dan kesempatan yang sama bagi PNS untuk ikut serta dalam kegiatan pengembangan kompetensi paling sedikit 20 (dua puluh) jam per tahun.

Berdasarkan kewenangan yang dimiliki sesuai ketentuan perundang-undangan di atas BPSDM Provinsi Jambi menyusun serangkaian program kerja pengembangan kompetensi PNS yang terdistribusikan ke dalam 4 (empat) bidang sesuai struktur organisasi dan tata kerja BPSDM yang baru. Program kerja yang disusun oleh masing-masing bidang disusun melalui sebuah kajian dan didasarkan pada hasil inventarisasi kebutuhan pengembangan kompetensi di setiap perangkat daerah melalui kegiatan wawancara kepada para pejabat structural yang menguasai tugas pokok dan fungsi perangkat daerah tersebut

\section{KAJIAN PUSTAKA \\ Definisi Kompetensi}

Menurut Kamus Besar Bahasa Indonesia, Kompetensi adalah kewenangan (kekuasaan) untuk menentukan (memutuskan Sesuatu), sementara menurut peraturan kepala BKN Nomor 7 Tahun 2013 tentang pedoman penyusunan standar kompetensi manajerial, kompetensi adalah:

Karakteristik dan kemampuan kerja yang mencakup aspek pengetahuan, keterampilan, dan sikap sesuai tugas dan fungsi jabatan.

Sementara menurut peraturan menteri dalam negeri nomor 75 Tahun 2016 tentang pusat penilaian kementerian Dalam negeri kompetensi adalah

Kemampuan dan karakteristik yang dimiliki oleh pegawai dan pegawai lainnya berdasarkan kompetensi manajerial, kompetensi teknis dan kompetensi social kultural yang di perlukan dalam pelaksanaan tugas jabatan.

Dengan demikian kompetensi diartikan sebagai sebuah karakteristik dan kemampuan kerja yang mencakup aspek pengetahuan, keterampilan, dan sikap sesuai tugas dan fungsi yang diperlukan dalam pelaksanaan tugas jabatan.

\section{Jenis Kompetensi}

Berdasarkan pasal 69 Undang-undang Nomor 5 Tahun 2014 tentang Aparatur Sipil Negara dan undang-undang Nomor 23 Tahun 2014 kompetensi yang harus dimiliki oleh aparatur sipil Negara khususnya di lingkungan kementerian negeri harus memiliki 4 jenis kompetensi yaitu: 
a. Kompetensi teknis adalah pengetahuan, keterampilan, dan sikap/perilaku yang dapat diamati, diukur, dan dikembangkan yang spesifik berkaitan dengan bidang teknis jabatan.

b. Kompetensi manajerial adalah pengetahuan, keterampilan, dan sikap/perilaku yang dapat diamati, diukur, dikembangkan untuk memimpin dan/atau mengelola unit organisasi.

c. Kompetensi social kultural adalah adalah pengetahuan, keterampilan, dan sikap/perilaku yang dapat diamati, diukur, dikembangkan terkait dengan pengalaman berinteraksi dengan masyarakat majemuk dalam hal agama, suku dan budaya, perilaku, wawasan kebangsaan, etika, nilai-nilai, moral, emosi dan prinsip, yang harus dipenuhi oleh setiap pemegang jabatan untuk memperoleh hasil kerja sesuai dengan peran, fungsi dan jabatan.

d. Kompetensi pemerintahan adalah karakteristik dan kemampuan kerja yang mencakup aspek pengetahuan keterampilan, dan sikap dalam memahami system penyelenggaraan urusan pemerintah

\section{Definisi Pengembangan Kompetensi}

Menurut BPSDM kementerian dalam negeri, pengembangan kompetensi didefinisikan sebagai Upaya sistematis untuk mendorong seorang pejabat agar memiliki kompetensi yang sepadan dengan standar kompetensi jabatannya. Menurut Pasal 206 Peraturan Pemerintah Nomor 11 Tahun 2017 tentang Manajemen PNS, pengembangan Kompetensi

Merupakan upaya utnuk pemenuhan kebutuhan kompetensi PNS dengan standar kompetensi jabatan dan rencana pengembangan karier. Dengan demikian pengembangan kompetensi merupakan suatu upaya yang sistematis untuk mendorong seorang PNS/Pejabat untuk memenuhi kebutuhan kompetensi sesuai dengan standar kompetensi jabatan dan rencana pengembangan karir.

\section{Pengembangan Kompetensi}

Bentuk pengembangan kompetensi yang dapat dilakukan untuk meningkatkan kompetensi PNS berdasarkan Pasal 210 Peraturan Pemerintah Nomor 11 Tahun 2017 tentang Manajemen PNS meliputi:

1. Pendidikan dilakukan untuk meningkatkan pengetahuan dan keahlian PNS melalui pendidikan formal dalam bentuk pemberian tugas belajar.

2. Pelatihan dilakukan melalui jalur pelatihan klasikal dan nonklasikal. Pelatihan klasikal proses pembelajaran tatap muka didalam kelas paling kurang melalui pelatihan, seminar, kursus dan penataran. Adapun pelatihan non klasikal dilakukan paling kurang melalui e-learning, bimbingan di tempat kerja, pelatihan jarak jauh, magang, dan pertukaran antara PNS dengan pegawai swasta.

\section{Kebijakan Pengembangan Kompetensi Berdasarkan Undang-Undang Nomor 5 Tahun 2014 dan Undang-Undang Nomor 23 Tahun 2014}

Pengembangan kompetensi PNS memiliki peran yang sangat besar dalam menjawab tantangan yang dihadapi baik local maupun global antara lain,

a. Kompetisi global yang harus dihadapi oleh seluruh lapisan masyarakat tak terkecuali oleh ASN;

b. Reformasi bidang politik yang cukup cepat dengan dinamika nya yang menuntut PNS lebih professional;

c. Korupsi yang masih menjadi penyakit bersama;

d. Rendahnya kepercayaan public terhadap birokrasi;

e. Rendahnya pelayanan public yang diberikan oleh PNS. 
f. Anggaran yang tidak efisien

Tantangan tersebut dapat diselesaikan oleh penyelenggaraan pengembangan kompetensi yang dilakukan lembaga yang kredibel dan professional untuk mewujudkan aparat yang professional.

Dalam rencana pembangunan jangka menengah nasional 2015-2019 telah ditetapkan tahapan pembangunan kualitas ASN yang dimulai dari penerapan Good Governance sampai dengan ASN sebagai Human Capital pada tahun 2025. Secara lengkap pentahapan pembangunan kualitas ASN sebagai berikut:

a. Penerapan Good Governance dilaksanakan pada RPJM 1 Tahun 2005-2009.

b. Reformasi Birokrasi dan perbaikan aturan (UU Nomor 5 Tahun 2014) dilaksanakan pada RPJM 2 Tahun 2010-2014.

c. Terciptanya Smart ASN dilaksanakan pada tahap RPJM 3 (2015-2019).

d. Menjadikan ASN sebagai Human Capital yang dilaksanakan pada tahapan RPJM 4 2020-2025.

e. Ditingkat peemerintah daerah, perbaikan kualitas ASN dilaksanakan melalui revisi peraturan tentang perangkat daerah yang menyesuaikan dengan terbitnya Undangundang Nomor 23 Tahun 2014 tentang pemerintah daerah. Dalam undang-undang tersebut pemerintah menyerahkan sebagian urusan pemerintah kepada daerah sehingga berdampak penyesuaian perangkat daerah yang ditandai dengan terbitnya peraturan pemerintah Nomor 18 tahun 2016 tentang perangkat Daerah.

f. Lahirnya peraturan pemerintah tersebut berakibat pada obyek pengembangan kompetensi yang menyesuaikan dengan urusan pemerintahan yang diberikan yang meliputi urusan konkuren, pilihan dan perangkat daerah pendukung. Selain berdasarkan urusan pemerintahan, pengembangan kompetensi juga menyasar pada peningkatan kompetensi manajerial, kompetensi teknis, kompetensi social kultura, dan kompetensi pemerintahan. Untuk level pimpinan, pengembangan kompetensi dilaksanakan untuk para pejabat pimpinan daerah seperti Bupati/Walikota, Anggota DPRD Kabupaten/Kota, Kepala Desa dan perangkat desa, jabatan pimpinan tinggi, administrator, pengawas, pelaksana, jabatan fungsional.

\section{METODE PENELITIAN}

Penulisan buku ini menggunakan metode deskriptif analitik adalah suatu metode yang berfungsi untuk mendeskripsikan atau memberi gambaran terhadap obyek yang diteliti melalui data atau sampel yang telah terkumpul sebagaimana adanya tanpa melakukan analisis dan membuat kesimpulan yang berlaku untuk umum.

Adapun metode pengumpulan data dilakukan dengan cara wawancara langsung kepada responden untuk mendapatkan data primer. Responden yang hadir yaitu para kepala bidang di perangkat daerah di Provinsi Jambi sesuai urusan pemerintahan yang diwawancara. Data tersebut diolah oleh Kasubbid Pengelolaan Kelembagaan dan Tenaga Pengembangan Kompetensi yang secara langsung menginvertarisir kebutuhan pengembangan kompetensi.

Selain melalui wawancara, untuk mendapatkan data sekunder dilakukan melalui kajian terhadapa literatur-literatur yang tersedia terutama peraturan perundang-undangan yang berkaitan dengan pengembangan kompetensi.

\section{HASIL DAN PEMBAHASAN}

\section{Arah Kebijakan Umum Pengembangan Komptensi Kementerian Dalam Negeri Tahun} 2020

Kementerian Dalam Negeri melalui Badan Pengembangan Sumber Daya Manusia (BPSDM) dengan berpedoman pada Peraturan Pemerintah Nomor 18 Tahun 2016 tentang Perangkat Daerah dan Peraturan Menteri Dalam Negeri Nomor 5 Tahun 2017 tentang Pedoman 
Nomenklatur Perangkat Daerah Provinsi dan Daerah Kabupaten/Kota yang melaksanakan fungsi penunjang penyelenggaraan urusan pemerintah telah mengeluarkan surat edaran Nomor 891-1/1006/BPSDM tanggal 27 Februari 2017 Program Pengembangan SDM aparatur berbasis kompetensi diatur sebagai berikut:

1. Pengembangan Kompetensi Teknis Subtantif/Inti adalah pengembangan kompetensi yang berkaitan langsung dengan tugas fungsi dalam jabatan, yakni yang terkait dengan :

a. Urusan konkuren wajib pelayanan dasar (yang mencakup urusan pemerintahan bidang pendidikan, kesehatan, pekerjaan umum dan penataan ruang, perumahan rakyat dan kawasan pemukiman, trantibumlinmas dan social serta pilihan: Kelautan dan Perikanan, Pariwisata, Pertanian, Kehutanan, ESDM, Perdagangan, Perindustrian dan Transmigrasi).

b. Urusan konkuren wajib non pelayanan dasar (yang mencakup urusan pemerintahan bidang tenaga kerja, pemberdayaan perempuan dan perlindungan anak, pangan, pertanahan, lingkungan hidup, admindukcapil, pemberdayaan masyarakat dan desa, pngendalian penduduk dan keluarga berencana, perhubungan, komunikasi dan informatika, koperasi, usaha kecil dan menengah, penanaman modal, kepemudaan dan olahraga, statistic, persandian, kebudayaan, perpustakaan dan kearsipan).

c. Perangkat daerah penunjang yaitu sebagai pendukung pelaksanaan urusan pemerintah yang menjadi kewenangan daerah (Badan Daerah, Inspektorat, Sekretariat Dewan dan Sekretariat Daerah).

2. Pengembangan kompetensi teknis umum dan teknis pilihan adalah pengembangan kompetensi dasar yang harus dimiliki oleh setiap jabatan dalam melaksanakan tugas dan fungsinya, sedangkan pengembangan kompetensi teknis fungsional bagi yang menduduki jabatan fungsional, yakni yang terkait dengan :

a. Pengembangan kompetensi umum yang wajib dimiliki oleh setiap jabatan (system pemerintahan, manajemen pembangunan, wasbang, dll).

b. Pengembangan kompetensi pilihan yang harus dimiliki (social kultural) oleh stiap jabatan yang sesuai dengan daerahnya masing-masing (kompetensi lain diluar jabatannya).

c. Pengembangan kompetensi jabatan fungsional bagi yang akan atau sudah menduduki jabatan fungsional.

3. Pengembangan kompetensi manajerial adalah pengembangan kompetensi manajemen pemerintahan dan kepemimpinan, yakni yang terkait dengan :

a. Pengembangan kompetensi bagi pimpinan daerah (KDH/wakil $\mathrm{KDH}$, pimpinan/anggota DPRD, camat).

b. Pengembangan kompetensi bagi pimpinan tinggi utama, madya, dan pratama (teknis, kepemimpinan).

c. Pengembangan kompetensi kepemimpinan dan prajabatan bagi administrasi dan kader PNS.

4. Pengembangan kompetensi dalam rangka Sertifikasi kompetensi dan pengelolaan kelembagaan diperlukan dalam pelaksanaan pengembangan Sumber Daya Manusia serta penguatan kelembagaan BPSDM, yakni yang terkait dengan :

a. Sertifikasi kompetensi yang harus melalui uji kompetensi untuk mengukur kompetensi aparatur yang dibandingkan dengan standarisasi kompetensi jabatan tertentu termasuk pengelolaan kelembagaan Sertifikasi.

b. Pengelolaan kelembagaan pengembangan Sumber Daya Manusia dengan tujuan meningkatkan fungsi kelembagaan dan pengembangan komepetensi 
bagi tenaga pengembang kompetensi (tenaga pengajar/TOT/MOT/Asesor, pengelolaan sarana pengembangan / pembelajaran).

c. Pengelolaan sumber belajar dan kerjasama dengan sasaran peningkatan kinerja secara kelembagaan melalui pengembangan metode belajar, sarana pembelajaran, perangkat pembelajaran, serta pengembangan kerjasama.

\section{Program Pengembangan Kompetensi BPSDM Provinsi Jambi}

Berdasarkan arah pengembangan kompetensi Kementerian Dalam Negeri, program pengembangan kompetensi yang di rancang akan dilaksanakan oleh BPSDM Provinsi Jambi berdasarkan hasil asesmen yang disesuaikan dengan pembidangan di BPSDM Provinsi Jambi.

\section{KESIMPULAN DAN SARAN}

\section{Kesimpulan}

Berdasarkan uraian diatas dapat disimpulkan hal-hal sebagai berikut :

1. Pengembangan kompetensi merupakan suatu upaya yang sistematis untuk mendorong seorang PNS untuk memenuhi kebutuhan kompetensi sesuai dengan standar kompetensi jabatan dan rencana pengembangan karir;

2. Pelaksanaan kegiatan pengembangan kompetensi merupakan salah satu unsur dalam pengelolaan manajemen PNS dan menjadi bagian dari pengembangan karir;

3. Kegiatan pengembangan kompetensi di daerah memperhatikan pada pembagian urusan kewenangan sebagaimana diatur dalam lampiran undang-undang Nomor 23 Tahun 2014 tentang pemerintahan daerah;

4. Sinergitas program pengembangan kompetensi antara pemerintah melalui BPSDM Kementerian Dalam Negeri dengan Pemerintah Daerah Provinsi melalui BPSDM Provinsi Jambi mutlak diperlukan untuk secara bersama mencapai target world class apparatur.

5. Dalam upaya meewujudkan hal tersebut, Pemerintah Provinsi Jambi telah menyusun Program Pengembangan Kompetensi Provinsi Tahun 2020 dengan berpedoman pada hasil asesmen kepada para pejabat di perangkat daerah Provinsi;

6. Program-program yang disusun oleh BPSDM Provinsi Jambi akan dilaksanakan pada tahun 2020 manakala pagu anggaran BPSDM Provinsi Jambi disetujui oleh Tim Anggaran Pemerintah Daerah (TAPD).

\section{Saran}

Berdasarkan hasil pembahasan dan kesimpulan di atas, dalam kesempatan ini disampaikan saran untuk perbaikan kegiatan sejenis di masa yang akan datang

1. Pelaksanaan wawancara langsung untuk mnginventarisasi kebutuhan pengembangan kompetensi untuk perangkat daerah Provinsi merupakan hal baru dan baik untuk dilanjutkan hanya saja asesi yang dihadirkan oleh perangkat daerah seyogianya yang menguasai permasalahan sehingga kesenjangan kompetensi dapat diketahui lebih akurat.

2. Program-program pengembangan kompetensi yang telah disusun apabila akan diimplementasikan membutuhkan dana sehingga membutuhkan dukungan dari semua pihak agar anggaran untuk kegiatan tersebut diprioritaskan guna mencapai target world class apparatuss. 


\section{DAFTAR RUJUKAN}

Rossett, A. 1987. Training Need Assesment. Educational Technology Publication. Englewood Cliffs. New Jersey

Anonym. 1986. Modul Pelatihan Bagi Pelatih. Lembaga Administrasi Negara RI dan Dep. Transmigrasi, Jakarta.

Anonym. 1996. Modul Pengelola Pelatihan. Departemen Tenaga Kerja. Jakarta

Irawan, P. 1994. Analisis Kinerja. Jakarta

Marpaung. 1999. Training Need Assesment (TNA). LAN. Jakarta.

Suprapti, W., S. Ratna,. 2009. Analisis Kebutuhan Diklat (Bahan Ajar Pada Diklat TNA). Jakarta

Undang - undang Nomor 5 tahun 2014

Undang - undang Nomor 23 Tahun 2014

Peraturan Pemerintah Nomor 11 Tahun 2017

Peraturan Menteri Dalam Negeri Nomor 75 Tahun 2016

Peraturan Kepala BKN Nomor 7 Tahun 2013 